\title{
THE EFFECTIVENESS OF PROBLEM BASED LEARNING AND DISCOVERY LEARNING MODEL TOWARD LEARNING OUTCOME IN GEOGRAPHY ON STUDENTS WITH EXTERNAL LOCUS OF CONTROL
}

\author{
Beti Munawaroh $^{1}$ and Muhsinatun Siasah Masruri ${ }^{2}$ \\ ${ }^{1,2}$ Geography Education, Postgraduate Program, Yogyakarta State University \\ Jalan Colombo, No.1, Catur Tunggal, Depok, Sleman, Yogyakarta \\ Email : ${ }^{1}$ beti.munawaroh93@gmail.com, ${ }^{2}$ muhsinatun_siasah@uny.ac.id
}

Received 15 December 2018/ Revised 7 February 2019/ Accepted 12 February 2019/ Published Online 29 April 2019

\begin{abstract}
Based on the development in education, Indonesia has implemented a new curriculum called $\mathrm{K} 13$, in this curriculum, implementing the scientific approach is mandatory. Unsuitable learning model results in minimum students' learning outcome in geography. In addition, locus of control also affects the students' learning outcome since students with internal LoC are alway better than students with external LoC. To cope with this issue, a suitable learning model is necessary: PBL and DL model. A suitable model is expected to be able to improve students' learning outcome - the present study aimed to examine the effectiveness of PBL and DL towards students with external locus of control. The present study was categorized as experimental research with control group experiment. The sample of the study was sixty-two students of SMA Negeri 1 Sekadau Hulu Class X of IPS. They were selected using purposive sampling. T-test was used to analyze the data obtained from the questionnaire and test. The result of the study showed that the significance value was $.043<0.05$. It means that there is effectiveness different between PBL and DL on students with external locus of control in terms of their learning outcome in Geography.
\end{abstract}

Keywords: Problem Based Learning, Discovery Learning, External Locus of Control.

\section{Introduction}

Education holds an essential role in human life. By a high-quality education, a nation may move forward. By a high-quality education, a nation shall obtain an excellent quality of human resources. According to Ambarjaya (2012: 5-6), an education is carried out in three ways namely informal education, non-formal education, and formal education. Informal education is an educational process runs throughout life, where every individual obtains their values, attitudes, skills, and pieces of knowledge from their life experiences. Non-formal 
education is any organized and systematic activity outside a school system. While, formal education is any systematic and gradual activities, starts from elementary education until higher education level.

One of the scientific material learned in school is Geography. Geography as a learning subject is taught in accordance with the students' mental development at each educational level (Sumaatmadja 1988: 20). Based on the development in the world of education, Indonesia has implemented new curriculum namely Curriculum 2013, in which applying scientific approach is the requirement. However, based on the observation, schools in Indonesia, in carrying out the learning process, were still teacher-centered. The teacher explained the material based on the books or student's worksheet, while the students listened to and wrote down the teacher's explanation. This is the reason why the students' learning outcome for geography subject was low. In other words, a learning model may affect the students' learning outcome in geography.

Problem-based learning and discovery learning are two of many models of the scientific approach that are based on a problem. Problem based learning is a learning model involving students to solve problems in accordance with the surrounding environmental condition. Thereare five phase in implementing Problem Based Learning, namely: Problem serving, Organizing students, Group investigation, Result development and display, and investigation result evaluation (Arends, 2008: 71). While, discovery learning model is a learning that allows students perform exploration, there are six phases in implementing this model namely: stimulation, problem statement, data collection, data processing, verification dan generalization (Syah, 2004: 244).Through this learning model, the students are required to be active for the teacher's role is only as an advisor. The students obtain their knowledge independently. It is in line with David Hammer (1997) who states "in principle, students formulate their own questions and design, conduct, and present their own experiments."

In addition to the learning model, external locus of control also affects the students' learning outcome. Robbin and Judge (2009: 138) note that learning outcome may be affected by many factors, one of them is locus of control. It is an individual's believe in perceiving the factors lie behind their successes or failures they experience. Most of the previous studies found that students with internal locus of control have better performance than those with external locus of control in terms of learning outcome. A study conducted by Yuliana Septiani (2016:118-126) found that the learning outcome in the mathematics of group of students with internal locus of control is better than those of the students with external locus 
of control. It possibly happens since students with external locus of control is a type of person is lack of effort, they perceive that their successes are determined by fate, easy going, relaxed, and lead a pleasant life (Hans, 2000; Hattie, Marsh, Neill \& Richards, 1997). Kreitner, R. \& Kinicki, A. (2001:135) state that external locus of control tends to attribute key outcomes in their lives to environmental causes, such as lick or fate. It is in line with Winner (Woolfolk, 1990:319 who states that external locus of control is closely related to belief, confidence, pride, guilt, and pudency. In a study conducted by sihkabuden (1999:6869), it is found that there is a positive and significant correlation between achievement motivation and locus of control. High motivation and achievement make students more active and complete their task better, high-motivated students will also obtain high learning outcome. Based on the issues described above, the researcher intends to carry out an experiment on the effectiveness of problem-based learning and discovery learning on the learning outcome in geography for students with external locus of control.

\section{The Methods}

The present study was categorized as an experimental study with control group experimental design. In this design, the subject is placed randomly into groups and are exposed as independent variable by given a post-test, the post-test score was then used to compare the effectiveness. The population of the study was all students of SMA Negeri Sekadau Hulu. The sample of the study was sixty-two students of class X of IPS who were selected through purposive sampling technique. The experimental group of the study was determined based on the lowest mean score of the final exam from two classes. In order to determine the group of students with external locus of control, this study employed a questionnaire of 15 questions and two alternative answers. While, in measuring the effectiveness of problem-based learning and discovery learning model, pre-test and post-test were conducted.

\section{Result and Discussion}

Before given any treatment, the students were asked to fill a questionnaire of locus of control. The questionnaire provided two answers ('yes' with score 1 and 'no' with score 0 ). It aimed at finding out the students who are included in external locus of control. After that, the 
students worked on a pre-test. Then, problem-based learning and discovery learning model were implemented, then, the post-test was conducted. The maximum and minimum score of pre-test and post-test of the students with external locus of control are shown in the table below:

Table 1 The mean score of Problem Based Learning Model and Discovery Learning Model of the students with external locus of control.

\begin{tabular}{|c|c|c|c|c|}
\hline \multirow[t]{2}{*}{ Description } & \multicolumn{2}{|c|}{$\begin{array}{l}\text { Problem Based } \\
\text { Learning Model }\end{array}$} & \multicolumn{2}{|c|}{ Discovery Learning } \\
\hline & Pre-test & post-test & Pre-test & post-test \\
\hline mean & 55.51 & 72.40 & 43.66 & 84.12 \\
\hline Median & 57 & 70 & 40 & 84.5 \\
\hline Mode & 67 & 70 & 40 & 80 \\
\hline Minimum score & 20 & 50 & 20 & 50 \\
\hline Maximum score & 73 & 93 & 73 & 97 \\
\hline N-Gain & \multicolumn{2}{|c|}{0.37} & \multicolumn{2}{|c|}{0.72} \\
\hline
\end{tabular}

Source: Data 2018

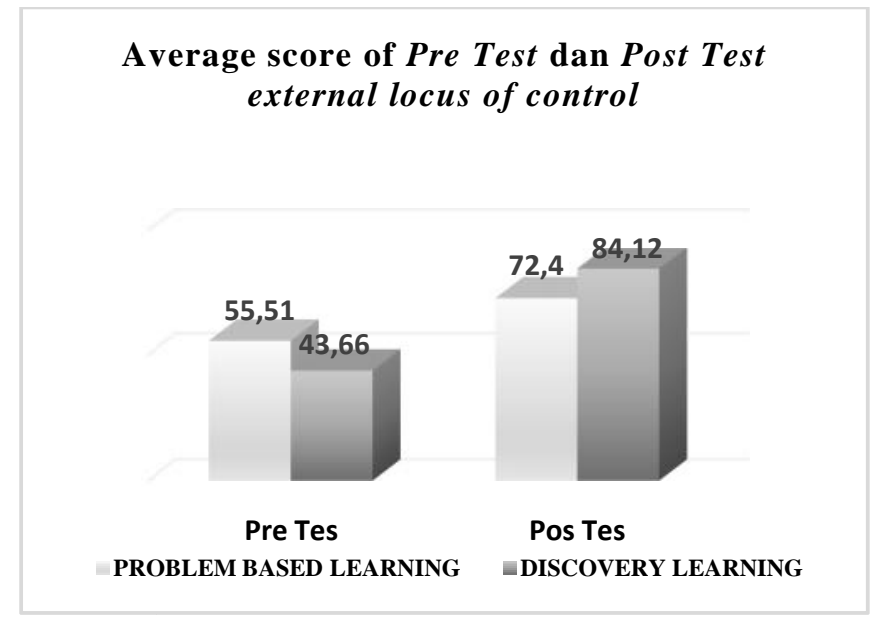

Figure 2. Graphic of Mean Score of the Students with External Locus of Control

The table above exhibits the result of pre-test and post-test on problem-based learning and discovery learning model. The average of students' pre-test result before treated by problem-based learning model was higher than the students' pre-test result before treated by discovery learning model. After treatment, the score of students who were treated using discovery learning was higher (84.12) than those treated using problem-based learning (72.4). It could be concluded that students with external locus of control are more effective when learning using discovery learning model than learning using the problem-based learning model. It is supported by the score n-gain on students treated by problem-based learning was 0.37 , and its effectiveness was categorized as intermediate. While, the n-gain score of students treated using discovery learning was 0.72 , its effectiveness for students with external locus of control was categorized as high. In other words, students with external locus of 
control suit better with discovery learning in improving students' learning outcome in geography.Elin (2016) also states that discovery learning mode is able to improve the students' learning outcome and make students become more active and creative. This statement is consistent with the result of study conducted by Fajar (2018) who states that there is an effectiveness difference between the use of discovery learning model and discovery learning model on the learning result.

The calculation result of students with external locus of control and problem-based learning and discovery learning are as follow:

Table 3. The t-test Analysis result of Students with External Locus of Control.

\begin{tabular}{ccccc}
\hline \multirow{2}{*}{ Learning Model } & \multicolumn{2}{c}{ External Locus of Control } & \multirow{2}{*}{ Frequency } & \multirow{2}{*}{ Sig } \\
\cline { 2 - 3 } & Pre-test & post-test & & \\
\hline Problem Based Learning & 52.93 & 74.14 & 27 & \multirow{2}{*}{0.043} \\
Discovery Learning & 42.91 & 85.17 & 35 & \\
\hline
\end{tabular}

Source: Data 2018

The table above describes the group of students with external locus of control toward the learning model. The group of external locus of control consisted of 62 subjects, 27 of them were treated using PBL, and the 35 of them were treated using DL. The significance value of the learning model on students with external locus of control was .040<0.05. Ha is accepted, and there is an effectiveness difference between problem-based learning and discovery learning on students with external locus of control in terms of their learning outcome in geography.

The present study aimed at examining the effectiveness of problem-based learning and discovery learning model in improving the learning outcome in geography of the students with external locus of control. An external is an individual whose orientation is directed to external factors such as being sociable. It can be concluded that an individual with external locus of control is an individual who is easy to interact and to socialize with his/her surroundings, and are also more active in various events, as well as possessing mode disclosure trait to people around him/her.It can be concluded that students with external locus of control suits better with discovery learning model. It is proven by the n-gain score that indicates that this model is categorized as highly effective compared to a problem-based learning model.

The result above supports the study conducted by Karwono (2007) which finds that experimental study on students to organize microlearning is effective for the group of students with external locus of control. Dhanisusanti (2018) states that discovery learning 
model is more effective than the problem-based learning model in terms of students' critical thinking and activeness. Ratna (2016) finds that there is an interaction between learning model and locus of control in affecting learning outcome in geography. It is found that the cognitive aspect $\mathrm{p}=0,002$, affective aspect $\mathrm{p}=0,000$, and psychomotor aspect $\mathrm{p}=0,001$ on $\alpha$ $=0,05 / 2$ (cognitive, affective, and psychomotor aspect $\mathrm{p}$ value $<\alpha=0,05 / 2$ ). Mahmoud, A. K. K. (2004) states that discovery learning manages in teaching language in developing skills. The model assist in employing learning activity where they learn the situation independently.

\section{Conclusion}

Student with external locus of control is more effective when learning using discovery learning model than learning using the problem-based learning model. N-Gain of students who learn using discovery learning model was 0.72. Its effectiveness for students with external locus of control was categorized as high. The significance value between learning model on students with external locus of control was .043 < 0.05 . It means Ha is accepted and there is an effectiveness difference between problem-based learning and discovery learning on students with external locus of control in terms of their learning outcome in geography.

\section{References}

Ambarjaya, Beni S. (2012). Psikologi Pendidikan \&Pengajaran (Teori\&Praktik). Yogyakarta: Caps

Hammer. David (1997). Discovery Learning And Discovery Teaching. Journal. Published By: Taylor \& Francis, Ltd. Source: Cognition And Instruction, Vol. 15, No. 4 (1997), Pp. 485-529

Hattie, J. A., Marsh, H. W., Neill, J. T. \& Richards, G. E. (1997) Adventure Education And Outward Bound: Outofclass Experiences That Have A Lasting Effect. Review Of Educational Research, 67, 43-87.

Karwono (2007). Pengaruh Pemberian Umpan Balik Dan Locus Of Control Terhadap Kemampuan Mahasiswa Dalam Mengelola Pembelajaran Mikro (Studi Eksperimen Pada Mahasiswa FKIP Universitas Muhammadiyah Lampung)

Kreitner, R., Dan Kinicki, A. (2001) Organizational Behavior. Fifth Edition. Irwin McgrawHill

Robbins, Stephen P \& Timothy A. Jugdge. (2009). Organizational Behavior. 13 Three Edition, Usa: Pearson International Edition, Prentice-Hall 
Septiani, Yulia. (2016) PengaruhLocus Of Control Terhadap Prestasi Belajar Matematika. Jurnal.JKPM, Vol.02, No.01, 01 Des 2016, Hlm. 118-128

Sihkabuden. (1999). Hubungan Antara Gaya Kognitif, Motivasi Berprestasi, Dan Lokus Kendali Dengan Perolehan Belajar Siswa SMU. Ilmu Pendidikan-Jurnal Filsafat, Teori, Dan Praktik Kependidikan, 26(2): 154-161.

Susanti, Dhani. (2018) PerbedaanPengaruh Discovery Learning Dan Problem Based Learning Terhadap Kemampuan Berpikir Kritis, Keterampilan Pemecahan Masalah Dan Keaktifan Siswa Dalam Pembelajaran Tematik Integratif Kelas IV SD Segugus Winduaji Kabupaten Brebes. Thesis.Tidak Diterbitkan. Universitas Negeri Yogyakarta, Yogyakarta.

Syatriadin. (2017) Locus Of Control: TeoriTemuanPenelitian Dan Reorientasinya Dalam Manajemen Penanganan Kesulitan Belajar Pesert aDidik. Journal Pendidikan Dasar. Issn2579-6194; 144-164

Pangestika, Ratna Pramudita (2016). Model Inquiry, Model Discovery, Locus Of Control, Hasil Belajar Geografi. Thesis. Tidak Diterbitkan. Universitas Negeri Yogyakarta, Yogyakarta.

Woolfolk, Anita, E. (1990). Educational Psychology-Fourth Edition. New Jersey: Prentice Hall. 